\title{
Glosa do UCHWAŁy SĄDU NAJWYŻSZEGo Z DNIA 20 WRZEŚNIA 2018 R., I KZP 5/18
}

Teza uchwały: Zakresem art. 218 § 1a KK objęte sa tylko osoby będace pracownikami w rozumieniu art. $2 \mathrm{KP}$ i art. $22 \S 1 \mathrm{i} \S 1$ [1] $\mathrm{KP}$, a więc osoby zatrudnione na warunkach charakterystycznych dla stosunku pracy, niezależnie od nazwy zawartej przez strony umowy; ustaleń w tym zakresie dokonuje w procesie karnym sąd, zgodnie z zasada jurysdykcyjnej samodzielności wyrażona w art. 8 § $1 \mathrm{KPK}^{1}$.

Glosowane orzeczenie stanowi kolejną wypowiedź Sądu Najwyższego na temat pojęcia pracownika, którym ustawodawca posługuje się w treści przepisów rozdziału XXVIII Kodeksu karnego², zatytułowanego Przestępstwa przeciwko prawom osób wykonujących pracę zarobkową. Wpisuje się ono w linię orzeczniczą wyznaczoną przez Sąd Najwyższy w uchwale z dnia 15 grudnia 2005 r. (I KZP 34/05) $)^{3}$ oraz w postanowieniu z dnia 13 kwietnia 2005 r. (III KK 23/05)4. W judykatach tych jednak Sąd Najwyższy wyznaczył zakres znaczeniowy terminu „pracownik”, dokonując wykładni art. 220 K.k., a komentowane orzeczenie dotyczy pojęcia

* Dr, Uniwersytet Mikołaja Kopernika w Toruniu; e-mail: m_sz@umk.pl, https:// orcid.org/0000-0003-1975-1309.

* Mgr, Uniwersytet Mikołaja Kopernika w Toruniu; e-mail: r.badowiec@umk.pl, https:/ / orcid.org/0000-0001-7912-1363.

1 Uchwała SN z dnia 20 września 2018 r., I KZP 5/18, Legalis nr 1822231.

2 Ustawa z dnia 6 czerwca 1997 r. - Kodeks karny, tekst jednolity: Dz. U. z 2020 r. poz. 1444 z późn. zm. (dalej: K.k.).

3 OSNKW 2006, nr 1, poz. 2.

4 OSNKW 2005, nr 7-8, poz. 69. 
pracownika na gruncie przepisu art. 218 § 1a K.k., który typizuje przestępstwo złośliwego naruszenia praw pracownika wynikających ze stosunku pracy lub ubezpieczenia społecznego.

Podjęte przez Sąd Najwyższy zagadnienie niewątpliwie cechuje się doniosłością teoretyczno-prawną oraz praktyczną. Jedną z głównych tendencji rozwojowych prawa pracy jest zacieranie się różnic pomiędzy tzw. zatrudnieniem pracowniczym i niepracowniczym oraz zrównywanie praw pracowników oraz osób wykonujących pracę na podstawie umów cywilnoprawnych. Zakres karnoprawnej ochrony praw osób wykonujących pracę zarobkową pozostaje jednak wciąż uzależniony od podstawy prawnej zatrudnienia. Przestępstwo z art. 218 § 1a K.k. jest skierowane jedynie przeciwko prawom pracowników w rozumieniu art. 2 Kodeksu pracy $^{5}$, co wynika z wąskiego ujęcia tego pojęcia nadanego w drodze interpretacji przez Sąd Najwyższy.

Komentowane orzeczenie zapadło na tle następującego stanu faktycznego. W dniu 27 listopada 2017 r. prokurator Prokuratury Rejonowej w D. zatwierdził postanowienie o odmowie wszczęcia dochodzenia w sprawie o naruszenie praw pracowniczych wynikających ze stosunku pracy przez M. Sp. z o.o. na szkodę m.in. M.W., czyli o czyn z art. 218 $\S 1$ 1a K.k., na podstawie art. 17 § 1 pkt 2 Kodeksu postępowania karnego ${ }^{6}$ wobec uznania braku znamion czynu zabronionego. Prokurator Prokuratury Rejonowej w D., działający w charakterze oskarżyciela publicznego, wskazał, że pokrzywdzony zatrudniony był na podstawie umowy cywilnoprawnej. W związku z tym wykluczało go to z kręgu podmiotów zaliczanych do pracowników w rozumieniu art. 2 K.p., a więc osób objętych ochroną na podstawie przepisu art. 218 § 1a K.k. Pokrzywdzony wniósł zażalenie na postanowienie prokuratora Prokuratury Rejonowej w D. o odmowie wszczęcia postępowania przygotowawczego. Wyjaśnił przy tym, że w rzeczywistości zatrudniony był w ramach stosunku pracy, a sama umowa nazwana została dla pozoru "umową o dzieło". Sąd Rejonowy w D. przy rozpoznawaniu zażalenia pokrzywdzonego uznał, że wyłoniło się zagadnienie prawne, które wymaga zasadniczej wykładni ustawy. W związku z tym zwrócił się do Sądu Najwyższego z pytaniem

5 Ustawa z dnia 26 czerwca 1974 r. - Kodeks pracy, tekst jednolity: Dz. U. z 2020 r. poz. 1320 (dalej: K.p.).

6 Ustawa z dnia 6 czerwca 1997 r. - Kodeks postępowania karnego, tekst jednolity: Dz. U. z 2020 r. poz. 30 z późn. zm. (dalej: K.p.k.). 
prawnym, czy w przepisie art. 218 § 1a K.k. pod pojęciem „pracownika” należy rozumieć tylko osobę zatrudnioną na podstawie umowy o pracę, wyboru, mianowania lub spółdzielczej umowy o pracę, czy także osobę, która wykonuje pracę zarobkową na podstawie umów cywilnoprawnych, jak np. umowa zlecenie lub umowa o dzieło, albo taką osobę, która pod pozorem wykonywania umowy cywilnoprawnej świadczy w rzeczywistości pracę w ramach stosunku pracy. Prokurator Prokuratury Krajowej wniósł o odmowę podjęcia uchwały. Sąd Najwyższy uznał jednak, że wystąpienie przez Sąd Rejonowy w D. z zagadnieniem prawnym spełniło warunki uregulowane $w$ przepisie art. $441 \S 1$ K.p.k., ponieważ miało charakter prawny, dotyczyło kwestii wymagającej zasadniczej wykładni ustawy oraz wyłoniło się przy rozpoznaniu środka odwoławczego.

Sąd Najwyższy, udzielając odpowiedzi na pytanie prawne, sformułował dwie zasadnicze tezy. Po pierwsze uznał, że znaczenie terminu ,ppracownik", którym posłużono się w art. 218 § 1a K.k., powinno być ustalane za pomocą norm i definicji pochodzących z prawa pracy ${ }^{7}$. Po drugie zaznaczył, że wspomnianemu terminowi nie można nadawać znaczenia szerszego niż funkcjonujące $\mathrm{w}$ prawie pracy, gdyż stanowiłoby to niedozwoloną wykładnię na niekorzyść oskarżonego, kolidującą z zasadą nullum crimen sine lege. Tezy sformułowane przez Sąd Najwyższy zasługują na aprobatę.

W tytule rozdziału XXVIII K.k. ustawodawca posłużył się zwrotem „osoba wykonująca pracę zarobkową". Pojęcie to obejmuje swoim zakresem znaczeniowym zarówno pracowników wykonujących pracę zarobkową $\mathrm{w}$ ramach stosunku pracy (zatrudnienie pracownicze), jak i osoby wykonujące pracę zarobkową $\mathrm{w}$ ramach niepracowniczych form zatrudnienia, tj. w ramach stosunków prawnych niebędących stosunkiem pracy (zatrudnienie niepracownicze). Należy zauważyć, że termin „pracownik" nie występuje w treści wszystkich przepisów rozdziału XXVIII K.k. Posłużono się nim dla sprecyzowania znamion czynu zabronionego z art. 218 § 1a K.k. oraz art. 220 § 1 K.k. W art. 218a K.k., dodanym przez art. 13 ustawy z dnia 10 stycznia 2018 r. o ograniczeniu handlu w niedziele i święta oraz niektóre inne dni ${ }^{8}$, ustawodawca wprowadził sformułowanie „pracownikowi lub zatrudnionemu”. Z kolei w treści art. 219 oraz 221 K.k. termin „pracownik” w ogóle nie występuje. W dyspozycji zarówno

7 Takie stanowisko zajął Sąd Najwyższy również w uchwale z dnia 15 grudnia 2005 r. (I KZP 34/05) oraz w postanowieniu z dnia 13 kwietnia 2005 r. (III KK 23/05).

8 Tekst jednolity: Dz. U. z 2019 r. poz. 466. 
art. 219 K.k., jak i art. 221 K.k. ustawodawca wyraźnie nie zastrzegł, że przedmiotem ochrony są wyłącznie prawa osób wykonujących pracę zarobkową posiadających status pracownika. Świadczy to o tym, że przedmiot ochrony zindywidualizowany w poszczególnych normach rozdziału XXVIII K.k. nie jest identyczny9.

Ponad to analiza treści art. 218a K.k. prowadzi do wniosku, że ustawodawca w sposób wyraźny dokonał rozróżnienia pomiędzy pojęciami pracownika a zatrudnionego, na co zwrócił uwagę w komentowanej uchwale Sąd Najwyższy. Należy także wspomnieć, że z terminologią rozdziału XXVIII K.k., w tym z jego tytułem, bardziej korespondowałoby wprowadzenie do art. 218a K.k. zwrotu „pracownikowi lub innej osobie wykonującej pracę zarobkową" albo „osobie wykonującej pracę zarobkową".

Pojęcie pracownika nie zostało zdefiniowane na potrzeby K.k. w jego art. 115. Jest to główny argument przemawiający za zasadnością tezy sformułowanej przez Sąd Najwyższy, aby znaczenie tego terminu ustalać w oparciu o normy prawa pracy ${ }^{10}$. Teza ta $\mathrm{w}$ pełni zasługuje na aprobatę. Podnieść również wypada, że dla sprecyzowania znamion czynu zabronionego z art. 218 § 1a K.k., oprócz pojęcia pracownika, posłużono się także innymi terminami z zakresu prawa pracy, które nie zostały zdefiniowane na potrzeby tegoż Kodeksu. W art. 218 § 1a K.k. mowa jest o prawach wynikających ze stosunku pracy. Jego definicja legalna została sformułowana $\mathrm{w}$ art. 22 $\S 1$ K.p. Nie ulega wątpliwości, że pojęcie stosunku pracy nie jest tożsame z pojęciem jakiegokolwiek stosunku prawnego, w ramach którego świadczy się pracę zarobkową, a w szczególności ze stosunkiem cywilnoprawnym. Prawa ze stosunku pracy przysługują osobom, które posiadają status pracownika w rozumieniu art. $2 \mathrm{w}$ zw. $\mathrm{z}$ art. $22 \S 1$ K.p. A contrario - co do zasady - takie prawa nie przysługują osobom nieposiadającym statusu pracownika, chyba że przepis prawa lub umowa tak stanowi. Ponadto w świetle art. 218 § 1a K.k. podmiot przestępstwa stanowi osoba, która wykonuje czynności w sprawach z zakresu prawa pracy. Przedmiotowych czynności pracodawca może dokonywać osobiście, jeżeli jest osobą fizyczną. Z kolei za pracodawcę będącego jednostką organizacyjną czynności w sprawach z zakresu prawa pracy wykonuje osoba lub organ zarządzający tą jednostką

9 Por. uzasadnienie uchwały SN z dnia 15 grudnia 2005 r., I KZP 34/05, OSNKW 2006, nr 1, poz. 2.

10 Podobnie: SN w uzasadnieniu uchwały z dnia 15 grudnia 2005 r., I KZP 34/05, OSNKW 2006, nr 1, poz. 2. 
albo inna wyznaczona do tego osoba (art. $3^{1} \S 1$ K.p.). Przepis ten stosuje się odpowiednio do pracodawcy będącego osobą fizyczną, jeżeli nie dokonuje on osobiście czynności w sprawach z zakresu prawa pracy (art. $3^{1} \S 2$ K.p.). Pojęcie czynności w sprawach z zakresu prawa pracy, którym posłużono się w art. $3^{1}$ K.p., nie zostało zdefiniowane na gruncie przepisów K.p. Wśród przedstawicieli doktryny prawa pracy panuje communio opinis co do tego, że obejmuje ono swoim zakresem znaczeniowym zarówno oświadczenia woli, jaki i inne działania o charakterze prawnym ${ }^{11}$. Podkreśla się ponadto, że nie należy stosować wykładni rozszerzającej, uznając, że w pojęciu czynności w sprawach z zakresu prawa pracy mieszczą się również te z zakresu ubezpieczeń społecznych ${ }^{12}$. Uzasadnione wydaje się zatem dekodowanie pojęć czynności z zakresu ubezpieczeń społecznych oraz osoby ich dokonującej w oparciu o przepisy prawa ubezpieczeń społecznych, a w szczególności ustawy z dnia 13 października 1998 r. o systemie ubezpieczeń społecznych ${ }^{13}$.

Przedstawione argumenty natury terminologicznej oraz zastosowanie reguł wykładni systemowej i funkcjonalnej w pełni uprawnia do sformułowania tezy, że na gruncie art. $218 \S 1$ 1a K.k. dobrem chronionym są prawa pracownika (art. $2 \mathrm{w}$ zw. z art. $22 \S 1$ K.p.) wynikające ze stosunku pracy (art. 22 § 1 K.p.). Dyspozycją normy z art. 218 § 1a K.k. nie są jednak objęte naruszenia praw osób wykonujących pracę zarobkową w ramach stosunków prawnych niebędących stosunkiem pracy w rozumieniu art. $22 \S 1$ K.p. i nieposiadające statusu pracownika w rozumieniu art. $2 \mathrm{w}$ zw. $\mathrm{z}$ art. $22 \S 1$ K.p., a w szczególności prawa osób wykonujących pracę zarobkową w ramach stosunków cywilnoprawnych. Należy zauważyć, że ustawodawca niejednokrotnie w sposób wyraźny dokonuje rozróżnienia pomiędzy pracownikiem a osobą świadczącą pracę $\mathrm{w}$ ramach niepracowniczych form zatrudnienia, chociażby na gruncie przepisów K.p. ${ }^{14}$, ustawy z dnia 23 maja 1991 r. o związ-

11 Zob. w szczególności: K.W. Baran, w: Kodeks pracy. Komentarz, red. K.W. Baran, Warszawa 2016, s. 43; L. Florek, Ł. Pisarczyk, Prawo pracy, Warszawa 2019, s. 60; T. Zieliński, G. Goździewicz, w: Kodeks pracy. Komentarz, red. L. Florek, Warszawa 2017, s. 69.

12 K.W. Baran, w: Kodeks pracy. Komentarz, red. K.W. Baran, s. 42.

13 Tekst jednolity: Dz. U. z 2020 r. poz. 266 z późn. zm.

14 Przepis art. 211 K.p. określa ogólne oraz szczegółowe obowiązki pracownika w zakresie przestrzegania przepisów i zasad bezpieczeństwa i higieny pracy. Z kolei art. $304^{1}$ K.p. stanowi, że obowiązki, o których mowa w art. 211, w zakresie określonym przez pracodawcę lub inny podmiot organizujący pracę, ciążą również na osobach fizycznych wykonujących pracę na innej podstawie niż stosunek pracy w zakładzie pracy lub $\mathrm{w}$ miejscu wyznaczonym przez pracodawcę lub inny podmiot organizujący pracę, a także 
kach zawodowych (tekst jednolity: Dz. U. z 2019 r. poz. 263) ${ }^{15}$, ustawy z dnia 3 grudnia 2010 r. o wdrożeniu niektórych przepisów Unii Europejskiej dotyczących równego traktowania (tekst jednolity: Dz. U. z 2020 r. poz. 2156) ${ }^{16}$ czy też rozdziału XXVIII K.k., o czym była już mowa.

Desygnaty terminu "pracownik”, którym posłużono się w art. 218 § 1a K.k., należy wyznaczać, odwołując się do materialnoprawnej definicji pracownika $\mathrm{z}$ art. 2 K.p., która została sformułowana dla całego systemu prawa pracy i ma charakter uniwersalny ${ }^{17}$, nie zaś do definicji przyjmowanych na potrzeby poszczególnych ustaw, w tym z zakresu prawa pracy i ubezpieczeń społecznych ${ }^{18}$.

W myśl art. 2 stosowanego $\mathrm{w}$ ZW. $\mathrm{z}$ art. $22 \S 1$ i $1^{1} \mathrm{~K}$.p. pracownikiem jest:

1) osoba zatrudniona na podstawie umowy o pracę, powołania, wyboru, mianowania lub spółdzielczej umowy o pracę (art. 2 K.p.) i wykonująca pracę $\mathrm{w}$ warunkach charakterystycznych dla stosunku pracy, zdefiniowanego $w$ art. $22 \S 1$ K.p.;

2) osoba wykonująca pracę $w$ warunkach charakterystycznych dla stosunku pracy, zdefiniowanego $\mathrm{w}$ art. $22 \S 1$ K.p., mimo że umowa stanowiąca podstawę zatrudnienia nie stanowi jednej z enumeratywnie wymienionych $\mathrm{w}$ art. 2 K.p. podstaw nawiązania stosunku pracy.

W literaturze z zakresu prawa pracy zauważa się, że „przy ocenie świadczenia pracy przez osobę, której przyznajemy status pracowniczy,

na osobach prowadzących na własny rachunek działalność gospodarczą, w zakładzie pracy lub w miejscu wyznaczonym przez pracodawcę albo inny podmiot organizujący pracę.

15 Od 1 stycznia 2019 r. obowiązuje znowelizowany art. 1 ustawy o związkach zawodowych. Przepis pkt 3 tegoż artykułu stanowi, że pracownikiem w rozumieniu przepisów przedmiotowej ustawy jest osoba, o której mowa w art. 2 K.p. Z kolei w myśl pkt 1 art. $1^{1}$ znowelizowanej ustawy o związkach zawodowych przez osobę wykonującą pracę zarobkową należy rozumieć pracownika lub osobę świadczącą pracę za wynagrodzeniem na innej podstawie niż stosunek pracy, jeżeli nie zatrudnia do tego rodzaju pracy innych osób, niezależnie od podstawy zatrudnienia, oraz ma takie prawa i interesy, które mogą być reprezentowane i bronione przez związek zawodowy.

${ }_{16} \mathrm{~W}$ art. 4 pkt 2 ustawy o wdrożeniu niektórych przepisów Unii Europejskiej dotyczących równego traktowania $\mathrm{w}$ zatrudnieniu mowa jest o warunkach podejmowania i wykonywania działalności gospodarczej lub zawodowej, w szczególności w ramach stosunku pracy albo pracy na podstawie umowy cywilnoprawnej.

17 K.W. Baran, w: Kodeks pracy. Komentarz, red. K.W. Baran, s. 25.

18 Zob. w szczególności: art. 8 ust. 1 oraz ust. 2a ustawy o systemie ubezpieczeń społecznych; art. 3 pkt 29 ustawy z dnia 29 listopada 2000 r. - Prawo atomowe, tekst jednolity: Dz. U. z 2019 r. poz. 1792 z późn. zm. 
istotna jest nie tylko nazwa podstawy zatrudnienia, która dla pozoru może być inaczej określona, co materialna treść wzajemnych zobowiązań podmiotów stosunku prawnego. O jego charakterze decyduje zgodny zamiar stron i cel umowy, a nie literalne brzmienie zawartych w niej postanowień" 19 . Przedstawiciele doktryny i judykatury zwracają uwagę, że dokonując kwalifikacji stosunku prawnego, w ramach którego jest świadczona praca, należy zwracać szczególną uwagę na faktyczny sposób realizacji zobowiązania ${ }^{20}$.

W glosowanym orzeczeniu Sąd Najwyższy podkreśla, że nadawanie zwrotowi „pracownik” w art. 218 § 1a K.k. znaczenia szerszego niż funkcjonujące obecnie $\mathrm{w}$ prawie pracy stanowiłoby niedozwoloną wykładnię na niekorzyść oskarżonego, która pozostaje w sprzeczności z jedną z naczelnych zasad prawa karnego - nullum crimen sine lege. Należy w pełni zgodzić się ze stanowiskiem Sądu Najwyższego. Przywołana zasada chroni jednostkę przed arbitralnym posługiwaniem się represją karną przez organy państwowe. Przewiduje ona, że zakaz dokonywania określonych zachowań, z którego przekroczeniem wiąże się kara, musi być określony $\mathrm{w}$ ustawie $\mathrm{w}$ formie generalnej i abstrakcyjnej ${ }^{21}$. Zgodnie $\mathrm{z}$ art. 1 \& $1 \mathrm{~K} . \mathrm{k}$. odpowiedzialności karnej podlega tylko ten, kto popełnia czyn zabroniony pod groźbą kary przez ustawę obowiązującą w czasie jego popełnienia. Formuła nullum crimen, nulla poena sine lege poenali anteriori oznacza, że bez ustawy nie ma przestępstwa ani kary oraz że ustawa nie działa wstecz. Zasada ujęta w art. 1 K.k. obejmuje cztery reguły szczegółowe: zasadę nullum crimen, nulla poena sine lege scripta, przez co należy rozumieć nakaz określoności przestępstwa i kary przez ustawę; zasadę nullum crimen, nulla poena sine lege certa, która zakazuje tworzenia niedookreślonych i nieostrych typów przestępstw i nieokreślonych kar grożących za przestępstwo; zasadę nullum crimen, nulla poena sine lege praevia, zawierającą zakaz nadawania

19 G. Goździewicz, w: System prawa pracy, t. 2. Indywidualne prawo pracy. Część ogólna, red. G. Goździewicz, Warszawa 2017, s. 116-117.

20 T. Zieliński, G. Goździewicz, w: Kodeks pracy. Komentarz, red. L. Florek, Warszawa 2017, s. 192; A. Kijowski, Podstawa i treść stosunku zatrudnienia a ubezpieczenia społeczne, Przegląd Ubezpieczeń Społecznych i Gospodarczych 2001, z. 10, s. 4; wyrok SN z dnia 13 kwietnia 2000 r., I PKN 584/99, OSNP 2001, nr 21, poz. 637; wyrok SN z dnia 7 lipca 2000 r., I PKN 727/99, LEX nr 1223707; wyrok SN z dnia 5 maja 2010 r., I PK 8/10, LEX nr 602668.

21 P. Kokot, Nullum crimen sine lege jako dyrektywa interpretacji tekstu prawnego, w: Nullum crimen sine lege, red. I. Sepioło, Warszawa 2013, s. 6. 
wstecznej mocy ustawie, jeżeli pogorszyłoby to sytuację prawną sprawcy oraz najważniejszą z punktu widzenia omawianych kwestii zasadę nullum crimen, nulla poena sine lege stricta, która stanowi o zakazie analogii i wykładni rozszerzającej na niekorzyść sprawcy czynu zabronionego ${ }^{22}$. Odwołując się do funkcji prawa karnego, czyli konieczności zapewnienia prewencyjnego oddziaływania zagrożenia karą, potrzebne jest określenie zarówno przestępstwa, jak i kary w generalnej normie prawnej - ustawie. Zasada nullum crimen sine lege ma znaczenie także z punktu widzenia winy. Aby można było przypisać ją sprawcy czynu, musi w momencie podjęcia decyzji o popełnieniu określonego zachowania istnieć czytelnie sformułowany ustawowy opis znamion przestępstwa ${ }^{23}$. W kontekście przywołanej wyżej zasady, leżącej u podstaw prawa karnego, należy w pełni podzielić stanowisko Sądu Najwyższego, że zakresem art. 218 § 1a K.k. objęte są tylko osoby będące pracownikami w rozumieniu art. 2 K.p. i art. $22 \S 1$ i $1^{1}$ K.p., a więc zatrudnione $\mathrm{w}$ warunkach charakterystycznych dla stosunku pracy, niezależnie od nazwy zawartej przez strony umowy.

W praktyce orzeczniczej sądów karnych trudności ze stosowaniem art. 218 § 1a K.k. pojawiają się w szczególności w sytuacjach, gdy praca jest wykonywana $\mathrm{w}$ warunkach charakterystycznych dla stosunku pracy wbrew nazwie zawartej przez strony umowy. Powstaje wówczas konieczność ustalenia, czy osoba, która świadczy pracę, posiada status pracownika, a w konsekwencji, czy podlega ochronie w myśl art. 218 § 1a K.k.

Nie ulega wątpliwości, że jeżeli praca jest wykonywana w warunkach charakterystycznych dla stosunku pracy wbrew nazwie zawartej przez strony umowy, zachodzi możliwość ustalenia istnienia stosunku pracy w postępowaniu sądowym. Może to nastąpić w procesie cywilnym. Sprawa o ustalenie istnienia stosunku pracy jest sprawą z zakresu prawa pracy (art. 476 $\S 1^{1}$ Kodeksu postępowania cywilnego $\left.{ }^{24}\right)^{25}$. Uprawnionymi do wytoczenia powództwa o ustalenie istnienia stosunku pracy są: osoba, która świadczy pracę $\mathrm{w}$ warunkach charakterystycznych dla stosunku pracy wbrew nazwie zawartej przez strony umowy, oraz inspektor pracy (art. 63 K.p.c.). Do

22 A. Grześkowiak, w: Kodeks karny. Komentarz, red. A. Grześkowiak, K. Wiak, Warszawa 2018, s. 14.

23 A. Barczak-Oplustil, Obowiazywanie zasady nullum crimen sine lege. Wybrane problemy, Czasopismo Prawa Karnego i Nauk Penalnych 2013, t. 17, z. 3, s. 22-24.

24 Ustawa z dnia 17 listopada 1964 r. - Kodeks postępowania cywilnego, tekst jednolity: Dz. U. z 2020 r. poz. 1575 z późn. zm. (dalej: K.p.c.).

25 Por. A.M. Świątkowski, Kodeks pracy. Komentarz, Warszawa 2006, s. 98. 
ustalenia istnienia stosunku pracy może dojść również w procesie karnym. Sąd karny rozstrzyga wówczas samodzielnie zagadnienia faktyczne i prawne, nie pozostając związanym rozstrzygnięciem innego sądu lub organu (art. 8 K.p.k.). Zasada samodzielności jurysdykcyjnej sądu jest jedną z najważniejszych zasad polskiej procedury karnej. Jej istota polega na samodzielnym kształtowaniu faktycznej i prawnej podstawy każdego rozstrzygnięcia (dotyczy to zarówno rozstrzygnięcia o głównym przedmiocie procesu, jak i wszelkich rozstrzygnięć o charakterze incydentalnym). Termin "zagadnienia faktyczne i prawne” należy rozumieć w sensie najszerszym. Obejmuje on ocenę prawną faktów, a także kwestię samych ustaleń faktycznych jako konieczną podstawę, z jakiej dopiero mogą się wyłonić konkretne zagadnienia prawne ${ }^{26}$. Wszelkie sytuacje, w których sąd karny będzie związany orzeczeniem innego sądu lub urzędu, stanowią wyjątki w procesie karnym. Do tego rodzaju wyjątków nie należą w szczególności orzeczenia sądów pracy $\mathrm{w}$ sprawie ustalenia istnienia stosunku pracy. $\mathrm{W}$ uchwale $\mathrm{z}$ dnia 15 grudnia 2005 r. (I KZP 34/05) Sąd Najwyższy podkreśla, że orzeczenia w przedmiocie ustalenia stosunku pracy są rozstrzygnięciami o charakterze deklaratywnym i nie stanowią przeszkody do poczynienia przez sąd karny ustaleń odmiennych, jeżeli przemawiają za tym ujawnione dowody.

\section{Zakończenie}

Konkludując, wykładni pojęcia pracownika, którym posłużono się w art. 218 § 1a K.k., należy dokonywać w oparciu o normy prawa pracy. Zakresem art. 218 § 1a K.k. objęte mogą być zatem jedynie osoby będące pracownikami w rozumieniu art. 2 i art. $22 \S 1$ i $\S 1^{1}$ K.p., czyli zatrudnione na warunkach charakterystycznych dla stosunku pracy, niezależnie od nazwy zawartej przez strony umowy. Nie można zastosować wykładni rozszerzającej i pod pojęciem „pracownika” rozumieć również osoby, która wykonuje pracę zarobkową na podstawie umów cywilnoprawnych, np. umowy zlecenia lub umowy o dzieło, gdyż prowadziłoby to do naruszenia zasady nullum crimen sine lege. Przekonująca jest także teza, aby sąd karny, orzekając o popełnieniu przestępstwa $\mathrm{z}$ art. 218 § 1a K.k., dokonywał ustaleń dotyczących wykonywania pracy w warunkach charakterystycznych

\footnotetext{
26 A. Sakowicz, w: Kodeks postępowania karnego, red. A. Sakowicz, Warszawa 2018, s. 61.
} 
dla stosunku pracy wbrew nazwie zawartej przez strony umowy zgodnie z zasadą jurysdykcyjnej samodzielności wyrażoną w art. 8 § 1 K.p.k.

\section{Bibliografia}

\section{Źródła}

\section{Akty prawne}

Ustawa z dnia 17 listopada 1964 r. - Kodeks postępowania cywilnego, tekst jednolity: Dz. U. z 2020 r. poz. 1575 z późn. zm.

Ustawa z dnia 26 czerwca 1974 r. - Kodeks pracy, tekst jednolity: Dz. U. z 2020 r. poz. 1320.

Ustawa z dnia 23 maja 1991 r. o związkach zawodowych, tekst jednolity: Dz. U. z 2019 r. poz. 263.

Ustawa z dnia 6 czerwca 1997 r. - Kodeks karny, tekst jednolity: Dz. U. z 2020 r. poz. 1444 z późn. zm.

Ustawa z dnia 6 czerwca 1997 r. - Kodeks postępowania karnego, tekst jednolity: Dz. U. z 2020 r. poz. 30 z późn. zm.

Ustawa z dnia 13 października 1998 r. o systemie ubezpieczeń społecznych, tekst jednolity: Dz. U. z 2020 r. poz. 266 z późn. zm.

Ustawa z dnia 29 listopada 2000 r. - Prawo atomowe, tekst jednolity: Dz. U. z 2019 r. poz. 1792 z późn. zm.

Ustawa z dnia 3 grudnia 2010 r. o wdrożeniu niektórych przepisów Unii Europejskiej dotyczących równego traktowania, tekst jednolity: Dz. U. z 2020 r. poz. 2156.

Ustawa z dnia 10 stycznia 2018 r. o ograniczeniu handlu w niedziele i święta oraz niektóre inne dni, tekst jednolity: Dz. U. z 2019 r. poz. 466.

\section{Orzecznictwo}

Postanowienie SN z dnia 13 kwietnia 2005 r., III KK 23/05, OSNKW 2005, nr 7-8, poz. 69.

Uchwała SN z dnia 15 grudnia 2005 r., I KZP 34/05, OSNKW 2006, nr 1, poz. 2. Uchwała SN z dnia 20 września 2018 r., I KZP 5/18, Legalis nr 1822231.

Wyrok SN z dnia 13 kwietnia 2000 r., I PKN 584/99, OSNP 2001, nr 21, poz. 637. Wyrok SN z dnia 7 lipca 2000 r., I PKN 727/99, LEX nr 1223707.

Wyrok SN z dnia 5 maja 2010 r., I PK 8/10, LEX nr 602668.

\section{Literatura}

Barczak-Oplustil A., Obowiazywanie zasady nullum crimen sine lege. Wybrane problemy, Czasopismo Prawa Karnego i Nauk Penalnych 2013, t. 17, z. 3. 
Florek L., Pisarczyk Ł., Prawo pracy, Warszawa 2019.

Kijowski A., Podstawa i treść stosunku zatrudnienia a ubezpieczenia społeczne, Przegląd Ubezpieczeń Społecznych i Gospodarczych 2001, z. 10.

Kodeks karny. Komentarz, red. A. Grześkowiak, K. Wiak, Warszawa 2018.

Kodeks postepowania karnego, red. A. Sakowicz, Warszawa 2018.

Kodeks pracy. Komentarz, red. L. Florek, Warszawa 2017.

Kodeks pracy. Komentarz, red. K.W. Baran, Warszawa 2016.

Nullum crimen sine lege, red. I. Sepioło, Warszawa 2013.

System prawa pracy, t. 2. Indywidualne prawo pracy. Część ogólna, red. G. Goździewicz, Warszawa 2017.

Świątkowski A.M., Kodeks pracy. Komentarz, Warszawa 2006.

\section{Streszczenie}

W komentowanej uchwale Sąd Najwyższy sformułował tezę, że znaczenie terminu „pracownik”, którym posłużono się w art. 218 § 1a K.k., powinno być ustalane za pomocą norm i definicji pochodzących z prawa pracy. Przestępstwo z art. 218 § 1a K.k. to przestępstwo jedynie przeciwko prawom pracowników w rozumieniu art. 2 K.p. oraz osób zatrudnionych na warunkach charakterystycznych dla stosunku pracy, niezależnie od nazwy zawartej przez strony umowy (art. 22 $\S 1^{1}$ K.p.). Stanowisko Sądu Najwyższego należy zaaprobować. Terminowi „pracownik" nie można nadawać znaczenia szerszego niż funkcjonujące w prawie pracy, gdyż stanowiłoby to niedozwoloną wykładnię na niekorzyść oskarżonego, kolidującą z zasadą nullum crimen sine lege. Przekonująca jest również teza, aby sąd karny, orzekając o popełnieniu przestępstwa z art. 218 § 1a K.k., dokonywał ustaleń dotyczących wykonywania pracy w warunkach charakterystycznych dla stosunku pracy wbrew nazwie zawartej przez strony umowy zgodnie z zasadą jurysdykcyjnej samodzielności wyrażoną w art. 8 § 1 K.p.k.

Słowa kluczowe: pracownik, art. 218 § 1a Kodeksu karnego, ustalenie istnienia stosunku pracy, zasada jurysdykcyjnej samodzielności sądu karnego

\section{GLOSS TO THE RESOLUTION OF THE SUPREME COURT OF 20 SEPTEMBER 2018, I KZP 5/18}

\section{Su m mary}

In the commented resolution, the Supreme Court formulated the thesis that the meaning of the term 'employee', used in Article 218 \& 1a of the Penal Code, should be determined by means of norms and definitions derived from the labor 
law. An offense under Article 218 § 1a of the Penal Code constitutes an offense only against employees' rights within the meaning of Article 2 of the Labor Code and in regard to persons employed under specific conditions to the employment relationship, regardless of the termed used by the parties in the contract (Article $22 \S 1^{1}$ of the Labor Code). The position of the Supreme Court should be approved. The term 'employee' cannot be given a broader meaning than that used within the labor law, as this would authorize an unlawful interpretation to the detriment of the accused, conflicting with the principle of nullum crimen sine lege. The thesis also attempts to convince that a criminal court, when deciding on the commission of an offense under Article $218 \S 1$ a of the Penal Code, made arrangements for the performance of work in the specific conditions to the employment relationship contrary to the term used by the parties in the contract in accordance with the principle of jurisdictional independence expressed in Article $8 \S 1$ of the Code of Criminal Procedure.

Key words: employee, Article $218 \S 1$ a of the Penal Code, determining the existence of an employment relationship, principle of jurisdictional independence of the criminal court

\section{КОММЕНТАРИЙ К ПОСТАНОВЛЕНИЮ ВЕРХОВНОГО СУДА OT 20.09.2018, I KZP 5/18}

\section{Резюме}

В комментируемом постановлении Верховный суд сформулировал тезис о том, что значение термина «работник», которое применялось в ст. 218 § 1а Уголовного кодекса, должно определяться посредством норм и дефиниций, вытекающих из трудового законодательства. Преступление по ст. 218 $\S 1$ У Уголовного кодекса это преступление только против прав работников по смыслу ст. 2 Трудового кодекса и лиц, нанятых на условиях, определенных для трудовых отношений, независимо от названия заключенного сторонами договора (ст. $22 \S 1^{1}$ Трудового кодекса). Позиция Верховного суда должна быть одобрена. Термин «работник» не может иметь более широкого значения, чем в трудовом праве, поскольку это было бы незаконным толкованием в ущерб обвиняемому, противоречащим принципу nullum crimen sine lege. Убедительным также является тезис, чтобы уголовный суд, принимая решение о совершении преступления, предусмотренного ст. 218 § 1 a Уголовного кодекса, принимал во внимание меры, касающиеся выполнения работ в условиях характерных для трудовых отношений, независимо от названия заключенного сторонами договора в соответствии с принципом 
юрисдикционной независимости, закрепленным в ст. 8 § 1 Уголовно-процессуального кодекса.

Ключевые слова: работник, ст. 218 § 1а Уголовного кодекса, определение наличия трудовых отношений, принцип юрисдикционной независимости уголовного суда 
